\title{
LIV. Description of two calculi composed of cystic oxide
}

\section{Thomas Taylor M.R.C.S.}

To cite this article: Thomas Taylor M.R.C.S. (1838) LIV. Description of two calculi composed of cystic oxide, Philosophical Magazine Series 3, 12:75, 337-338, DOI: $10.1080 / 14786443808649459$

To link to this article: http://dx.doi.org/10.1080/14786443808649459

册 Published online: 01 Jun 2009.

Submit your article to this journal $\sqsubset \pi$

Џll Article views: 2

Q View related articles $₫$ 
LIV. Description of two Calculi composed of Cystic Oxide. By Thomas Taylor, M.R.C.S.

To the Editors of the Philosophical Magazine and Journal. Gentlemen,

THE unfrequent occurrence of calculi composed of cystic oxide, induces me to believe that a description of two specimens of that substance would not be unacceptable to some of your readers. They were found among a number of unexamined calculi in the museum of St. Bartholomew's Hospital, which, by the kindness of Mr. Stanley, one of the surgeons of the establishment, and the anatomical lecturer, I was permitted to examine and arrange.

The larger specimen weighed 740 grs.; it was of an oval figure, somewhat flattened, measuring one inch nine tenths through the long axis, and respectively one inch four tenths and one inch one tenth through the two short axes. When sawn through it exhibited the confusedly crystallized structure characteristic of this species; the crystals apparently radiated from the centre, their summits projecting at its external surface; these were not however sufficiently defined to render their form evident. The whole had a light yellow colour, its sp. gr. $=1 \cdot 13$. When heated before the blowpipe, it emitted the peculiar odour of cystic oxide, and left a small ash, which was partially fusible. In all its other chemical relations it entirely agreed with that substance.

Ten grains of the sawings yielded by analysis :

Cystic oxide ............................... 9.10

Phosphate of lime ....................... 0.38

$\begin{array}{lll}\text { Phosphate of ammonia and magnesia... } & 0 \cdot 10\end{array}$

Animal matter and loss $0 \cdot 42$

\section{$10 \cdot 00$}

Uric acid could not be detected in it. As far as I am aware this specimen is the largest and finest upon record. Of the other the museum possessed only one half; it was of a lighter colour, and the crystalline structure was not so well marked. Crystallization appeared to have taken place from three points. It measured one inch seven tenths by one inch three tenths. Its exterior was coated in parts by a thin layer of the fusible calculus mixed with a little cystic oxide. Its chemical characters corresponded with the other, but when burnt, it left a much smaller residue, which was alkaline. Unfortunately no history has been preserved of either of these calculi, although there are strong grounds for believing

Phil. Mag. S. 3. Vol. 12. No. 75. April 1838. 2 I 
that the larger calculus was taken from the bladder of a young man after death, who during life had exhibited no symptoms of any affection of the urinary organs.

Should this meet with your approval, its insertion in your ensuing Number will much oblige,

March 13, 1838. Gentlemen, yours, \&c.,

Thomas Taylor, New Bridge Street, Blackfriars. M.R.C.S.

L.V. On the Composition of certain Mineral Substances of Organic Origin. By James F. W.Johnston, M.A., F.R.SS., L. and E., F.G.S., Professor of Chemistry and Mineralogy, Durham*.

II. Hatchetine.

THIS mineral is known to occur, though rarely, in connection with the iron ores of the coal measures in Glamorganshire, and in some of the Midland counties of England. The specimen to which the following description and analysis applies was from the former locality, "and I have been indebted for it to the liberality and kindness of Sir David Brewster.

It is transparent, yellowish, consists of thin laminæ of a nacreous lustre, has the consistence of soft wax, is greasy to the touch; at ordinary temperatures has no perceptible smell, but when heated emits a fatty odour. Its specific gravity at $60^{\circ} \mathrm{Fahr}$. is 0.916 , and it melts at about $115^{\circ} \mathrm{Fahr}$. I am in possession of too small a quantity to enable me to ascertain its boiling point. By a cautious application of heat it appears to distil over without change.

Exposed to the air for a length of time it blackens on the surface, and becomes opake, and it is found in most cabinets in this state. When melted, the black particles, probably charcoal from the slow decomposition of the mineral, float in the fluid and exhibit much lustre.

Boiling alcohol dissolves it very sparingly, and from the solution it is nearly all precipitated on cooling. Fther in the cold also dissolves a very small quantity; in boiling ether it is more largely soluble. On cooling, the solution coagulates into a mass of minute fibres (prisms), from which the æther may be separated by agitation or compression, and which have a crystalline nacreous lustre. In recent specimens the mineral is said sometimes to occur in large crystals, with the form of which I am unacquainted. After repeated boiling with æther there remains still a minute portion undissolved,

- Communicated by the Author. 